\title{
CASTRATION-INDUCED HYPERACTIVITY OF SEMINAL VESICLE IN THE CATFISH CLARIAS BATRACHUS: A CASE OF PARADOX AND BLOCKADE BY ANTIANDROGEN (CYPROTERONE ACETATE) TREATMENT
}

\author{
M. S. SingH and K. P. JoY* \\ Department of Zoology, Banaras Hindu University, Varanasi, India \\ (Received: April 28, 1999; accepted: November 4, 1999)
}

\begin{abstract}
Castration of the catfish Clarias batrachus in late preparatory-early prespawning phase (April-May) caused time-dependent stimulatory effect on morphology, weight, and in the concentrations of biochemical correlates, such as total proteins, fructose, hexosamines and sialic acid in the seminal vesicle (SV). The peak changes were noticed on week 4 of castration. The hyperactivity was related to augmented production of testosterone by the SV of castrates with the levels significantly high from week 3 onwards. As a result, serum testosterone level fluctuated with a significant decrease in the first and fifth weeks, a significant increase in the third week, and no significant difference in the second and fourth weeks. Serum $\mathrm{E}_{2}$ level decreased significantly throughout. Cyproterone acetate treatment (CA; $1 \mathrm{mg} /$ fish daily for 21 days) from the second day of castration decreased the size and weight of the SV and the concentrations of total proteins, hexosamines, fructose and sialic acid. The antiandrogen treatment did not alter serum testosterone level but the $\mathrm{E}_{2}$ level was significantly decreased. It is concluded that the hypersecretory activity of the SV in castrates is a sequel to local synthesis and action of testosterone and the effect could be prevented by CA by blocking androgen actions.
\end{abstract}

Keywords: Seminal vesicle - testis - catfish - castration - cyproterone acetate - testosterone - estradiol $17 \beta$ - total protein - fructose - hexosamine - sialic acid

\section{INTRODUCTION}

Seminal vesicle is a unique feature of the male reproductive system of catfishes, capable of both endocrine (steroidogenic) and exocrine functions [15, 21, 26, 29, 37]. It shows annual changes in its secretory activity in correlation with the testicular cycle as evident from histological, morphometric and gravimetric investigations [15, $20,28]$. The SV epithelial cells secrete into the vesicular lumina a carbohydrate-protein-lipid rich complex which serves as a nutritive and storage medium for spermatozoa. Recently, biochemical parameters such as total proteins, hexosamines, fructose, sialic acid and various classes of lipids were measured to assess SV secretory activity under seasonal and experimental conditions [25-30]. Their concentrations

\footnotetext{
*Corresponding author; E-mail: kpjoy@banaras.ernet.in
} 
showed correlative changes in both SV and testis. As the SV participates in different aspects of reproduction such as temporary sperm storage, promotion of sperm survival and fertilization ability and, as a source of steroid conjugate pheromones in synchronisation of spawning activity [32, 36, 37], its study assumes aquacultural importance, too.

Castration is the classical approach adopted to demonstrate pituitary-testis relationship and androgenic involvement in accessory reproductive organ function in vertebrates. It results in androgen deficiency and regressive changes in the accessory reproductive organs. But in teleosts with SV, castration (removal of testis) showed varied effects: regressive changes as in gobies [4] or hyperactivity as in catfishes Heteropneustes fossilis [32] and Clarias gariepinus [38]. According to Sundararaj and Nayyar [33,34], the hypersecretory activity of the SV in castrates was due to the low circulating level of androgens stimulating gonadotropin (GTH) secretion which, in turn, may act directly on the SV epithelium or indirectly through the steroidogenic interstitial cells of the SV or the interrenal cells to synthesize androgens. However, no hormonal data were provided by those authors to test either of the possibilities. Cyproterone acetate (antiandrogen, CA) treatment to a lesser extent, and $\mathrm{E}_{2}$ to a greater extent, suppressed the SV activity in castrates [34] by acting at the interrenal (the former) or the hypothalamo-hypophysial system (the latter). The purpose of the present study was to demonstrate changes in biochemical contents of the SV after castration and CA administration, and the hormonal mechanism underlying the hypersecretory activity of the SV during castration.

\section{MATERIALS AND METHODS}

\section{Collection and maintenance}

Catfish (60-65 g) were collected in late preparatory phase (April) of the annual reproductive cycle. Males were separated and maintained for 15 days for acclimation under natural photoperiod and temperature (LD cycle 12.45 : 11.15; ambient temperature $30.4 \pm 8.4{ }^{\circ} \mathrm{C}$ in April). The fish were treated with benzanthine penicillin (1 $000000 \mathrm{IU} /$ litre) daily for $1 \mathrm{~h}$ for three days to prevent infection. They were fed goat liver during acclimation and course of experiments.

\section{Initial control}

\section{Experimental design}

Sixty acclimatized fish were weighed and blood was collected by caudal puncture. The blood samples were allowed to clot at $4{ }^{\circ} \mathrm{C}$ and centrifuged at $4000 \mathrm{rpm}$ to separate serum. The serum was stored at $-20{ }^{\circ} \mathrm{C}$ for measurement of testosterone and estradiol-17 $\left(\mathrm{E}_{2}\right)$. The fish were sacrificed by decapitation. Seminal vesicles (SV) were removed quickly and weighed. They were stored at $-20{ }^{\circ} \mathrm{C}$ for estimation of various biochemical parameters. 


\section{Castration and sham castration}

Catfish were castrated or sham castrated as described earlier [24]. They were maintained separately under normal photoperiod and temperature (LD cycle 13.30 : 10.30; ambient temperature $31.93 \pm 7.1^{\circ} \mathrm{C}$ in May). Sixty fish each from the two groups were sacrificed 1, 2, 3, 4 and 5 weeks after the operation. The fish were weighed and blood was collected for serum collection. They were dissected out and the body cavity was thoroughly checked for any regeneration of the testis. Tissues/serum samples from completely castrated (testis removed) fish only were included for the study. The SVs were removed in toto, photographed and stored at $-20{ }^{\circ} \mathrm{C}$ for various biochemical estimations.

\section{Administration of cyproterone acetate (CA) in castrates}

Fish were collected in April and acclimatized for 15 days. They were divided into 4 groups of 60 each. Group 1 (initial control) fish were sacrificed before the start of the experiment for serum and tissue collection. Group 2 fish were sham castrated and injected daily with olive oil from the second day of operation for 21 days. Group 3 fish were castrated and injected with olive oil daily for 21 days. Group 4 fish were castrated and injected with CA (1 mg/fish/day i.p.) daily for 21 days from the second day of the operation.

On termination of the experiments, the fish were weighed, blood was withdrawn for serum collection, and the SVs were separated and weighed. They were stored at $-20{ }^{\circ} \mathrm{C}$ for biochemical estimations.

\section{Study parameters}

\section{a) SV-somatic index (SVSI)}

The SV weights were expressed in $100 \mathrm{~g}$ body weight.

\section{b) Estimation of total proteins, fructose, hexosamines and sialic acid}

The concentrations of total proteins, fructose, hexosamines and sialic acid in the SV were measured by the methods of Lowry et al. [9]; Mann [10]; Elson and Morgan [5], as modified by Davidson [2], and Warren [40], respectively.

\section{c) Radioimmunoassay (RIA) of serum testosterone} and estradiol- $17 \beta\left(\mathrm{E}_{2}\right)$

Testosterone and $\mathrm{E}_{2}$ RIAs were carried out according to the procedure of Abraham [1]. $\left[1,2,6,7,{ }^{3} \mathrm{H}(\mathrm{N})\right]$-testosterone (sp. act. $92.1 \mathrm{Ci} / \mathrm{mMol}$ ) and $\left[2,4,6,7,{ }^{3} \mathrm{H}(\mathrm{N})\right]-\mathrm{E}_{2}(\mathrm{sp}$. act. $87.0 \mathrm{Ci} / \mathrm{mMol}$ ) were purchased from NEN, Boston, MA, USA. Testosterone anti- 

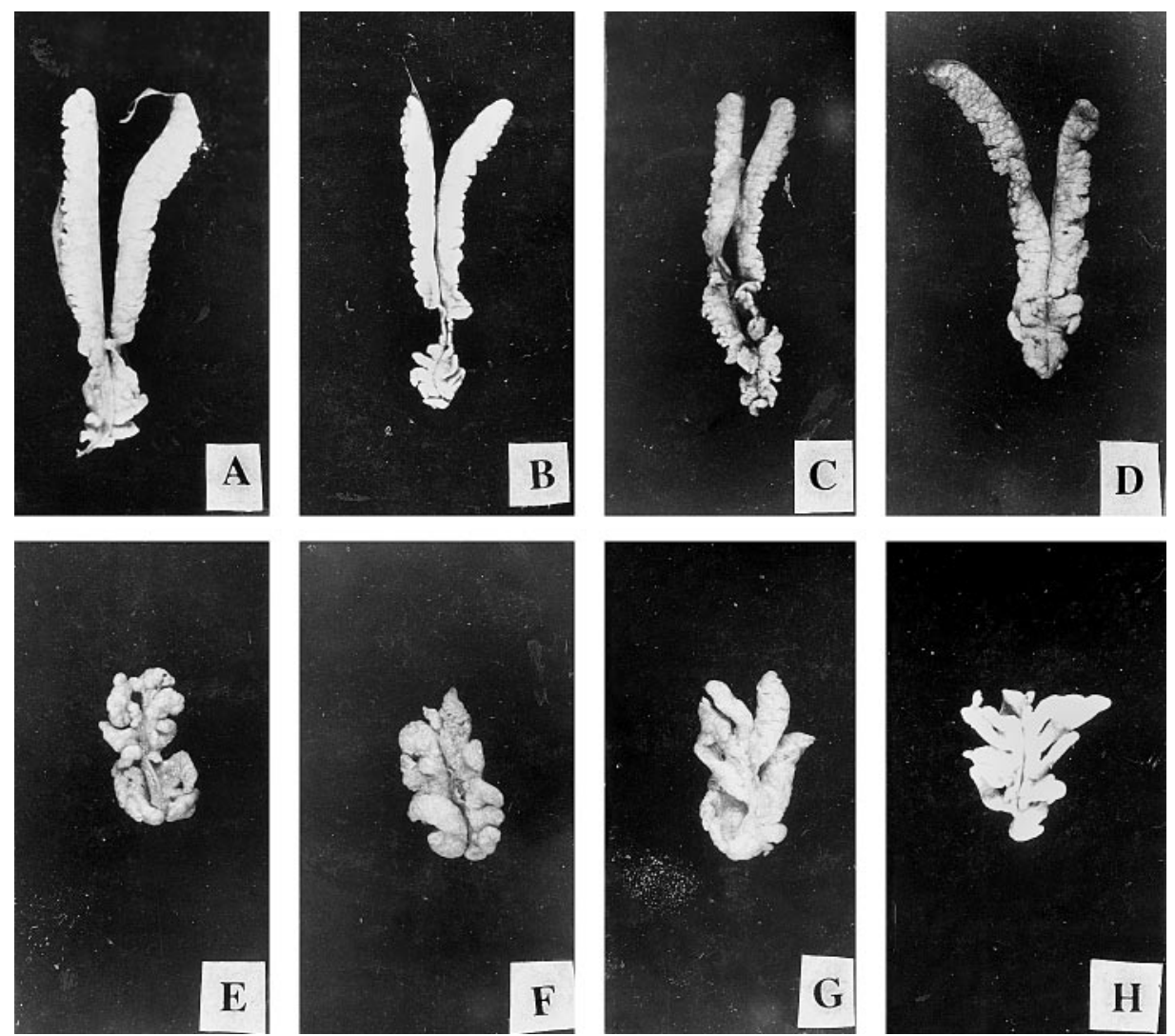

Fig. 1. (A-H) The male reproductive system of sham castrated (A-D) and the seminal vesicle (SV) of castrated (E-H) Clarias batrachus at 2, 3, 4 and 5 weeks, respectively. Note the increase in size of the $\mathrm{SV}$ which is maximal in the fourth week (Fig. 1G). $\times 1.5$

body was a generous gift of the Indian Council of Medical Research, New Delhi and Dr. C. Das, AIIMS, New Delhi and $\mathrm{E}_{2}$ antibody of Professor G. D. Niswender, Colorado State University, Fort Collins, Co., USA.

The sensitivity of both assays was $10 \mathrm{pg} / \mathrm{ml} . \mathrm{E}_{2}$ antiserum cross-reacted with estrone $(4 \%)$ and estriol $(0.5 \%)$. The testosterone antiserum cross-reacted with $5 \alpha$ dihydrotestosterone $(3 \%), \Delta^{4}$-androstenedione $(4.3 \%), 5 \alpha$-androstanediol $(1.9 \%)$, progesterone $(1.1 \%)$, androstane- $3 \alpha$-diol $(1.5 \%)$, cortisol $(0.096 \%)$, androstane- $3 \beta$ diol $(2.5 \%)$, estradiol-17ß $(0.061 \%)$ and dehydroisoandrosterone sulphate $(0.72 \%)$. The intra- and interassay coefficients of variation $(n=5$, mean $\pm S D)$ for $E_{2}$ were $2.28 \%(\mathrm{SD} \pm 0.011)$ and $5.3 \%(\mathrm{SD} \pm 0.025)$, respectively and those for testosterone were $1.43 \%(\mathrm{SD} \pm 0.014)$ and $2.40 \%(\mathrm{SD} \pm 0.023)$, respectively. 


\section{Statistical analysis}

Data were expressed as means \pm SEM (standard error of means). Data of different durations of castration were analyzed by one-way ANOVA (castration vs. duration), followed by Newman-Keuls' multiple range test. Student's $t$-test was used to find out the significance of the effect of cyproterone acetate.

\section{RESULTS}

\section{Effect of castration on morphology}

Castration caused initial regression and then hypertrophy of the SV depending on duration of the operation (Figs 1E-H). Comparison to that of the sham castrated fish is also shown (Figs 1A-D). The enlargement was maximal at week 4 of castration (Fig. 1G).

\section{Effect of castration on SVSI}

The SVSI showed significant increases at all durations of castration except week 1 registering peak increase at week 4 and declining thereafter (Fig. 2; $\mathrm{F}=56.67$; $p<0.001$; one-way ANOVA). Newman-Keuls' analysis showed that the increase in the fourth week was significantly higher than the second and fifth week values. Daily

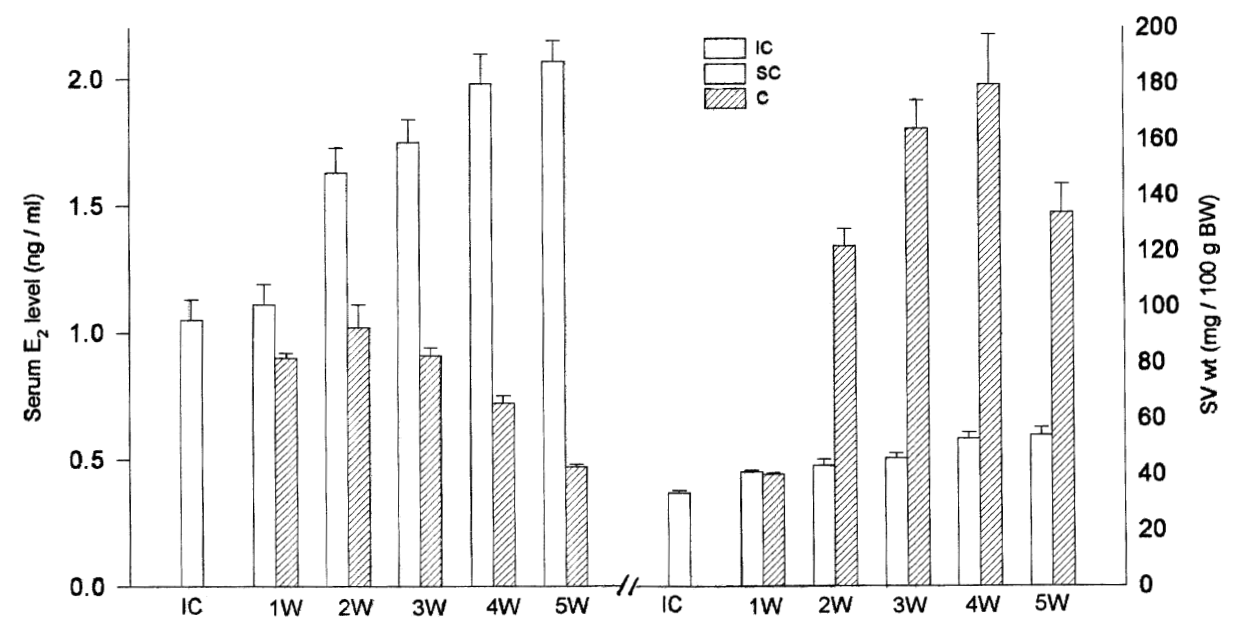

Fig. 2. Effect of castration on seminal vesicle somatic index (SVSI) and serum level of estradiol-17 $\beta\left(\mathrm{E}_{2}\right)$ (means $\pm \mathrm{SEM}, \mathrm{n}=5$ ) in Clarias batrachus; $\mathrm{IC}$ - initial control, $\mathrm{SC}$ - sham castrated, $\mathrm{C}$ - castrated, SV wt - seminal vesicle weight. One-way ANOVA and Newman-Keuls' test (see the text for details) 
injections of CA ( $1 \mathrm{mg} /$ fish) for 21 days in the castrated fish inhibited the SVSI significantly $(p<0.001)$ compared to those of the castrated and sham castrated groups (Fig. 6).

\section{Effect of castration on serum and SV testosterone, and serum $E_{2}$ levels}

Serum testosterone level (Fig. 3) showed a significant variation $(\mathrm{F}=17.37$, $p<0.001$, one-way ANOVA). The level decreased significantly in the first and fifth weeks, increased in the third week and changed only insignificantly in the second and fourth weeks. Newman-Keuls' analysis showed that the steroid level in the first

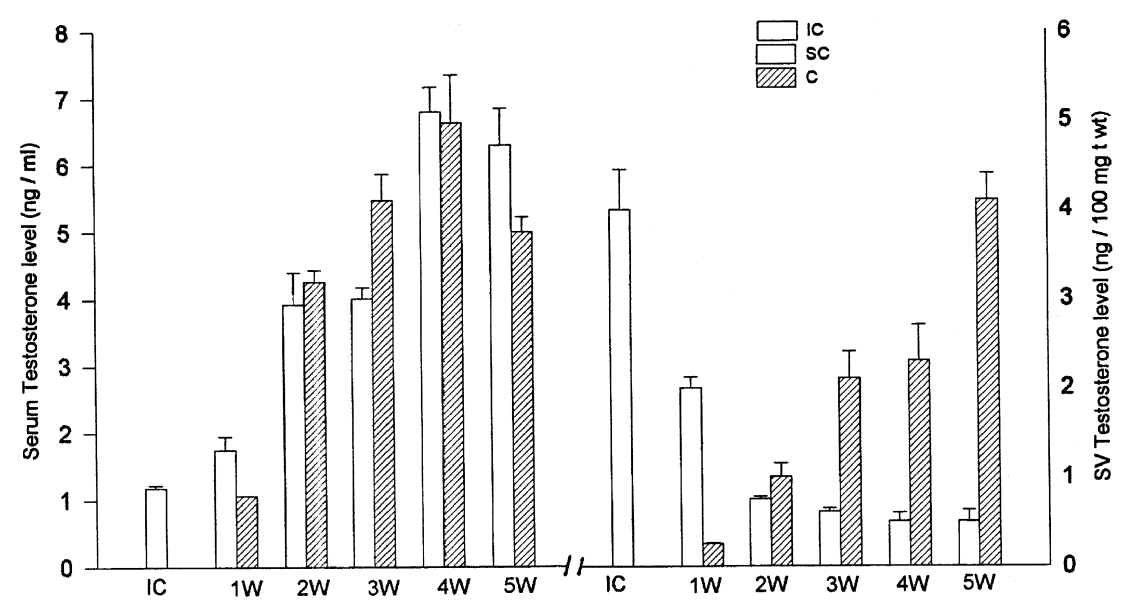

Fig. 3. Effect of castration on serum and seminal vesicle testosterone level (means $\pm S E M, n=5)$ in Clarias batrachus. Abbreviations as in Fig. 2. One-way ANOVA and Newman-Keuls' test (see the text for details)

week of castration was significantly lower than all other values. The second week value was significantly lower than the third and fourth week values. In the castrated fish, the SV testosterone level (Fig. 3) first decreased significantly in week 1, increased insignificantly in week 2 , and significantly in weeks 3,4 and $5(\mathrm{~F}=34.64$; $p<0.001$, one-way ANOVA). In the sham castrated fish, there was a significant increase of testosterone values compared to that of the initial control group. The serum level of $E_{2}$ showed a significant decrease throughout castration (Fig. 2) with the lowest value in the fifth week ( $\mathrm{F}=46.54, p<0.001$, one-way ANOVA). Newman-Keuls' analysis showed that the decrease of $E_{2}$ in the fifth week was significantly greater than all other values. The administration of CA in castrates did not influence the serum level of testosterone in the treatment groups but $\mathrm{E}_{2}$ level showed a further significant decrease over the castrated vehicle group (Fig. $5 ; p<0.001$ ). In 


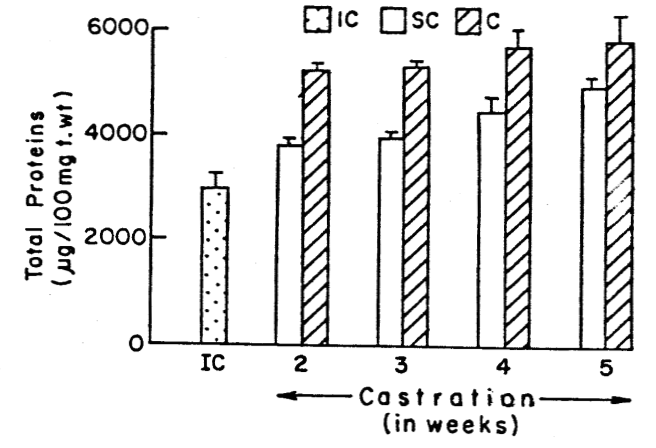

(A)
Đic $\square$ sc $\oslash c$

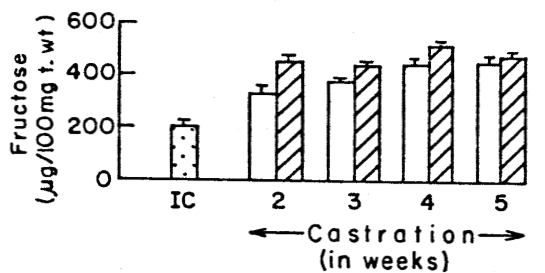

(B)

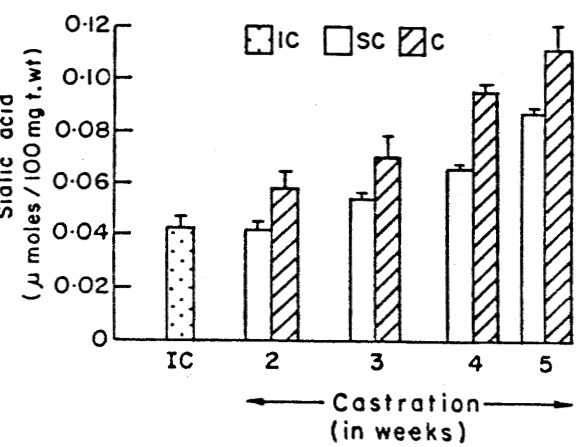

(D)

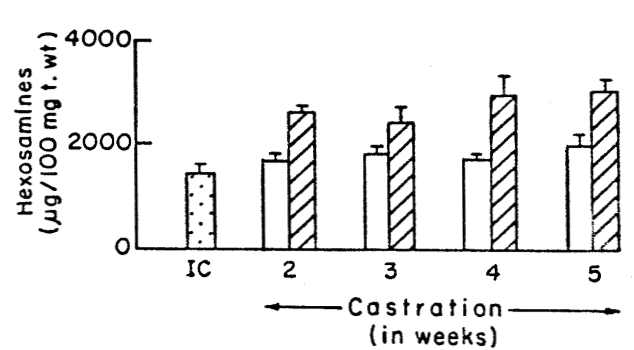

(C)

Fig. 4. Effects of different durations of castration on concentrations of total proteins (A), fructose (B), hexosamines (C), and sialic acid (D) in Clarias batrachus (means $\pm \mathrm{SEM}, \mathrm{n}=5$ ). Abbreviations as in Figure 2. One-way ANOVA and Newman-Keuls' test (see the text for details) 
this experiment, serum testosterone level in the castrated group did not vary significantly from the sham control group as in the previous experiment (3-week group) perhaps due to large standard deviation.

\section{Effect of castration on total protein concentration}

The concentration of total proteins increased significantly after castration $(\mathrm{F}=18.05$; $p<0.001$, ANOVA). Newman-Keuls' analysis showed that the values were significantly higher at 2, 3 and 4 weeks than the respective sham castrated group values (Fig. 4A). The administration of CA in the castrated fish decreased significantly the concentrations of total protein $(p<0.01$; Fig. 6$)$.

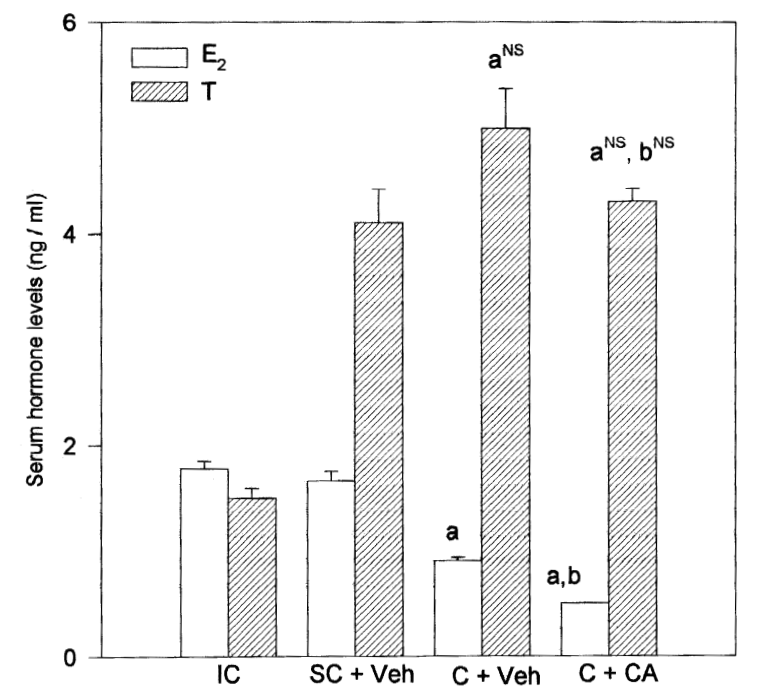

Fig. 5. Effects of cyproterone acetate (CA) administration on serum levels of estradiol-17 $\beta\left(\mathrm{E}_{2}\right)$ and testosterone levels (means $\pm \mathrm{SEM} ; \mathrm{n}=5$ ) in Clarias batrachus. The treatment was concurrent from day 2 of castration. a - comparison of sham control vehicle ( $\mathrm{SC}+\mathrm{Veh})$ group with castrated vehicle control $(\mathrm{C}+\mathrm{Veh})$ and castrated $\mathrm{CA}(\mathrm{C}+\mathrm{CA})$ groups. b - comparison between $\mathrm{C}+\mathrm{Veh}$ and $\mathrm{C}+\mathrm{CA}$ groups (Student's $t$-test, $p<0.001$ )

\section{Effect of castration on fructose concentration}

The concentration of fructose showed a significant variation $(\mathrm{F}=24.31 ; p<0.001$, ANOVA). The levels were significantly high only at the second and third weeks of castration. At other durations, the level was only insignificantly high (Fig. 4B). The administration of $\mathrm{CA}$ in the castrated fish decreased significantly the concentration of fructose ( $p<0.001$; Fig. 6$)$. 


\section{Effect of castration on hexosamine concentration}

The concentration of hexosamines showed a significant variation $(\mathrm{F}=6.41$; $p<0.001$, ANOVA). The levels were significantly high at all durations except the third week (Newman-Keuls' test) (Fig. 4C). The administration of CA in the castrated fish decreased only insignificantly the hexosamine level (Fig. 6).

\section{Effect of castration on sialic acid concentration}

The sialic acid concentration showed a significant variation $(\mathrm{F}=20.03, p<0.001$, ANOVA). The increase was not significant in the second and third weeks compared to the respective sham castrated group values but was significantly high in the fourth and fifth weeks. The increase in the fifth week was significantly higher than all other values (Fig. 4D). The administration of CA in the castrated fish decreased drastically the sialic acid level $(p<0.001$; Fig. 6$)$.

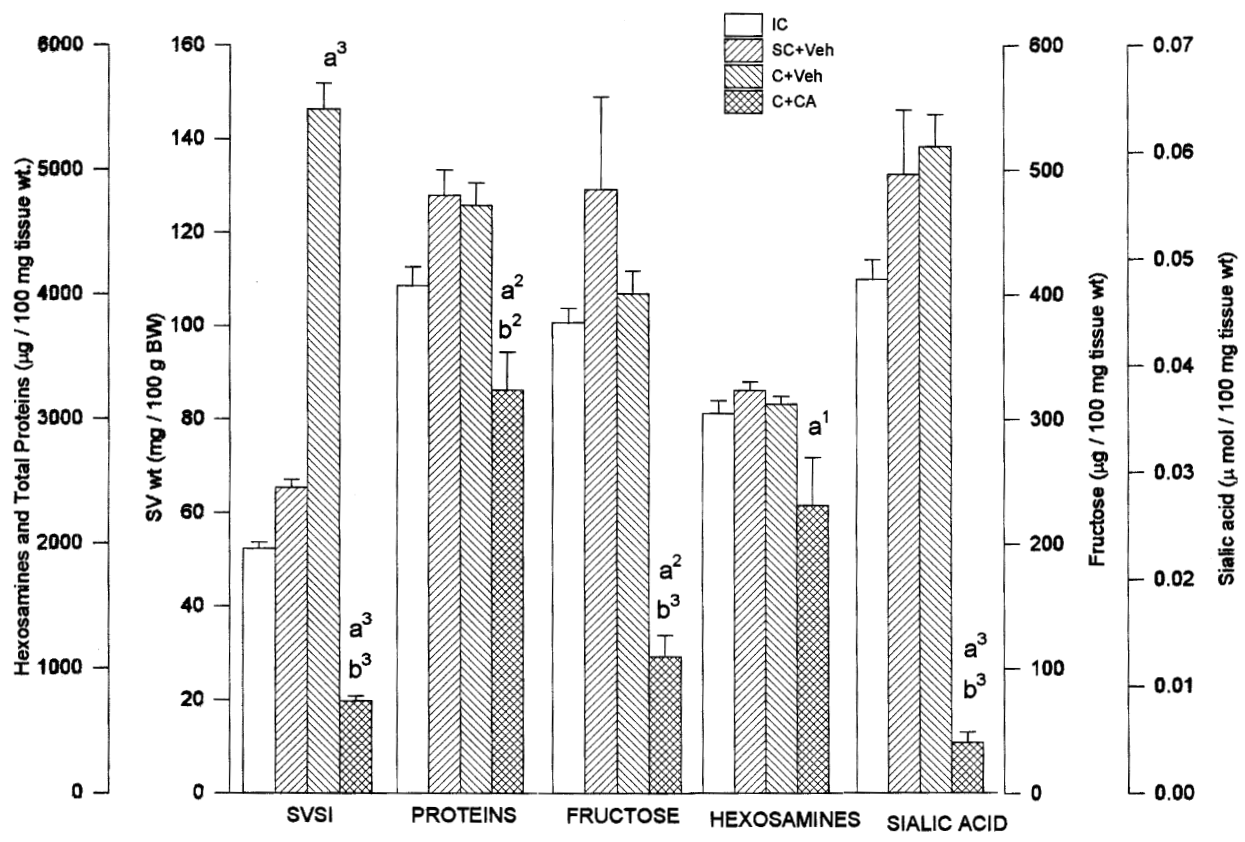

Fig. 6. Effect of cyproterone acetate (CA) administration on seminal vesicle (SV) weight, total proteins, fructose, hexosamines and sialic acid levels in Clarias batrachus (mean $\pm \mathrm{SEM} ; \mathrm{n}=5$ ). The treatment was concurrent from day 2 of castration. a - comparison of sham castrated vehicle $(\mathrm{SC}+\mathrm{Veh})$ group with castrated vehicle $(\mathrm{C}+\mathrm{Veh})$ and castrated $\mathrm{CA}(\mathrm{C}+\mathrm{CA})$ treated groups; $\mathbf{b}-$ comparison between $\mathrm{C}+\mathrm{Veh}$ and $\mathrm{C}+\mathrm{CA}$ groups. ${ }^{1} p<0.05 ;{ }^{2} p<0.01 ;{ }^{3} p<0.001$, Student's $t$ test 


\section{DISCUSSION}

The present data show that castration of the catfish produced hypersecretory activity of the SV as indicated by hypertrophy, increased SVSI, and elevated levels of total proteins, fructose, hexosamines, and sialic acid. Comparable hypersecretory responses in histology or SVSI were also reported in other catfishes viz., H. fossilis [33, 34] and C. gariepinus [38]. On the other hand, in gobies Bathygobius soporator [35] and Gillichthys mirabilis [4], regressive changes were reported after castration. The contradictory effects of castration may be due to whether the SV is steroidogenic or not. In catfishes, the SV secretes a variety of androgens, including testosterone [21, 22]. Castration resulted in elevated production of testosterone by the SV from week 3 onwards which, in turn, acted locally to stimulate the SV epithelium causing hypertrophy. Furthermore, the elevated production of testosterone by the SV could also maintain or elevate the serum titre of the steroid. Therefore, the hypothesis of Sundararaj and Nayyar [34] that androgens of interrenal origin are responsible for hyperactivity of the SV is not valid at least for this species. In H. fossilis (unpublished data of K. P. Joy and I. J. Chowdhury) and C. gariepinus [3] the plasma levels of testosterone and/or androstenedione were significantly low after the testes removal. The species difference can be attributed to the tissue mass/steroidogenic potential of the SV.

In earlier studies, the secretory activity of the SV following castration was assessed by changes in weight (SVSI) and histology [14, 33, 34]. We demonstrated that measurements of total proteins, fructose, hexosamines and sialic acid which are chemical components of SV secretion are better and direct means to ascertain the functional state of the $\mathrm{SV}$, as has been exhaustively investigated in mammalian epididymis and accessory sex organ activity [6, 11, 19, 39]. In mammals, castration led to reduction of these correlates due to androgen deprivation. Therefore, these correlates can be also used as markers of androgen status. In intact catfish, the administration of testosterone elevated the levels of these correlates in the SV [25]. Therefore, in the castrated fish, the paradoxical effect of hypersecretory activity of the SV was due to endogeneously synthesized testosterone. Even in mammalian species, castration elicits varied responses on the ultrastructure of SV, like abolition of secretory activity of epithelial cells as in rat, reduction but not loss of activity as in hamster or an intermediate state of activity compared to rat and hamster, as in mouse [12]. This has been attributed to an extra-testicular contribution of androgens such as from the adrenals.

It is well known that the accessory sex glands are target organs for androgens and, therefore, for antiandrogens [17]. CA has been shown to suppress SV activity in intact $C$. batrachus [28] and castrated H. fossilis [24, 34]. In castrated C. batrachus, the CA treatment not only blocked the castration-induced hypersecretory activity of the $\mathrm{SV}$, but also resulted in regressive changes compared to the sham control group. The CA treatment inhibited significantly the concentrations of total proteins, fructose and sialic acid but not the hexosamine content. Investigations in mammals have shown that CA inhibits the levels of proteins and sialic acid in the epididymis, and 
fructose in the Cowper's glands and dorsal prostate [18]. In the castrated catfish, the CA treatment did not alter the serum testosterone level. This is in contrast to reports of decreased androgen levels in CA-treated intact animals, like rainbow trout [13, 23], C. batrachus [28] and human volunteers and laboratory mammals [16]. The CAinduced regressive changes in the SV of the catfish can be ascribed to the antiandrogen competitively inhibiting the binding of testosterone to receptors in the SV. The androgen receptor dynamics in relation to CA treatment needs to be studied. The serum $E_{2}$ level registered significant decreases in castrates after the $C A$ treatment, perhaps due to decreased aromatisation or increased degradation. A decrease in $E_{2}$ level was also reported in CA-treated human volunteers [8]. Srivastava et al. [31] reported that $\mathrm{CA}$ displaced $\mathrm{E}_{2}$ selectively from sex hormone-binding globulin in female monkey plasma, leading to greater metabolism of $\mathrm{E}_{2}$.

The removal of the testis resulted in a hemi-castration-like effect on the SV which can be compared to compensatory hypertrophic phenomenon observed when one of the paired glands is removed surgically (e.g., adrenal, testis, ovary, etc.). The SV is suggested to have a common origin with the testis $[7,29,37]$ and, therefore, the hypertrophy of the SV following testis removal is a compensatory mechanism. Since the organs are located in an antero-posterior axis, the compensatory mechanism can be called anterior/posterior hypertrophy of structures of same origin or analogous function, like the interrenal (adrenal) and corpuscle of Stannius of teleosts. But a reciprocity of changes is not evident in case of testis - SV axis. Vesiculectomy (removal of the SV) does not produce any compensatory effect on the testis $[32,38]$. This is because the testis is such a robust organ of steroid synthesis that ablation of the SV may not make any impact on the steroid pool. The full steroidogenic potential of the SV can be observed only when the testis is knocked out. The compensatory hypertrophy can be attributed to GTH, in the absence of its testicular receptors, available in high titre to induce the receptors on the SV interstitial cells to augment steroid production. Further studies on the involvement of GTH receptor function in the SV of castrates are required.

\section{ACKNOWLEDGEMENTS}

This work was supported by a research grant of the Indian Councial of Agricultural Research, New Delhi to KPJ. The first author is grateful to the Council of Scientific and Industrial Research, New Delhi for a research associateship. The authors are grateful to Schering AG, Germany for a generous gift of cyproterone acetate, Prof. G. D. Niswender, Department of Physiology, University of Colorado, Co., USA for $\mathrm{E}_{2}$ antiserum, and the Indian Council of Medical Research, New Delhi and Dr. Chandana Das AIIMS, New Delhi for testosterone antiserum.

\section{REFERENCES}

1. Abraham, G. E. (1974) Radioimmunoassay of steroids in biological materials. Acta Endocrinol. 183 (Suppl. 75), 1-42.

2. Davidson, E. A. (1966) Analysis of sugars found in mucopolysaccharides. In: Neufeld, E. F., Ginsburg, V. (eds) Methods in Enzymology, Vol. VIII, Academic Press, New York, pp. 52-60. 
3. De Leeuw, R., Voorthius, Y. A., Zandbergen, M. A., Peute, J., Goos, H. J. T. (1986) The effect of aromatizable androgens, non-aromatizable androgens and estrogens on gonadotropin release in castrated African catfish, Clarias gariepinus (Burchell). A physiological and ultrastructural study. Cell Tissue Res. 243, 487-594.

4. De Vlaming, V. L., Sundararaj, B. I. (1972) Endocrine influences on seminal vesicles in the estuarine gobiid fish, Gillichthys mirabilis. Biol. Bull. 142, 243-250.

5. Elson, L. A., Morgan, W. T. J. (1933) A colorimetric method for the determination of glucosamine and galactosamine. Biochem. J. 27, 1824-1828.

6. Fawell, S. E., Higgins, S. J. (1986) Tissue distribution, developmental profile and hormonal regulation of androgen-responsive secretory protiens of rat seminal vesicles studied by immunocytochemistry. Mol. Cell. Endocrinol. 48, 39-49.

7. Fishelson, L., Van Vuren, J. H. J., Tyran, A. (1994) Ontogenesis and ultrastructure of seminal vesicles of the catfish, Clarias gariepinus. J. Morph. 219, 59-71.

8. Knuth, U. A., Hano, R., Nieschlag, E. (1984) Effect of flutamide or cyproterone acetate on pituitary and testicular hormones in normal men. J. Clin. Endocrinol. Metab. 59, 963-969.

9. Lowry, O. H., Rosebrough, N. J., Farr, A. L., Randall, R. J. (1951) Protein measurement with folinphenol reagent. J. Biol. Chem. 193, 265-275.

10. Mann, T. (1964) The Biochemistry of Semen and of the Male Reproductive Tract. Methuen, London.

11. Mann, T., Lutwak-Mann, C. (1981) Male Reproductive Function and Semen: Themes and Trends in Physiology, Biochemistry and Investigative Andrology. Springer-Verlag, Berlin.

12. Mata, L. R., David-Ferreira, J. F. (1985) Secretory cell activity in the hamster seminal vesicle following castration. A morphometric ultrastructural study. Biol. Cell 53, 165-178.

13. Murphy T. M. (1980) The effect of methallibure and cyproterone acetate on the gonadotrophic cells, plasma androgen levels and testes of precocious $1+$ male Atlantic salmon parr Salmo salar (L.). J. Fish Biol. 17, 673-680.

14. Nayyar, S. K., Sundararaj, B. I. (1969) Effects of pituitary hormones, androgens, and corticosteroids on the seminal vesicles of the castrate catfish, Heteropneustes fossilis (Bloch). J. Exp. Zool. 172, 385-398.

15. Nayyar, S. K., Sundararaj, B. I. (1970) Seasonal reproductive activity in the testes and seminal vesicles of the catfish, Heteropneustes fossilis (Bloch). J. Morph. 130, 207-226.

16. Neumann, F., Habenicht, U. F., Schacher, A. (1984) Androgens and target cell response: different in vivo effects of cyproterone acetate, flutamide and cyproterone. In: McKerns, K. W., Aakvaag, A., Hansson, V. (eds) Regulation of Target Cell Responsiveness, Vol. 2, Plenum, New York, pp. 489-527.

17. Neumann, F., Richter, K. D., Schenck, B., Tunn, U., Senge, T. (1980) Action of antiandrogens on accessory sexual glands. In: Schroder, F. H., de Voogt, H. J. (eds) Steroid Receptors, Metabolism and Prostatic Cancer. Excerpta Medica, Amsterdam, pp. 22-40.

18. Prasad, M. R. N., Rajalakshmi, M., Reddy, P. R. K. (1971/72) Action of cyproterone acetate on male reproductive functions. Hormones and Antagonists: Gynec. Invest. 2, 202-212.

19. Price, D., Williams-Ashman, H. G. (1961) The accessory reproductive glands of mammals. In: Young, W. C. (ed.) Sex and Internal Secretions, Vol. I, Third edition Williams and Wilkins, Baltimore, pp. 366-448.

20. Rastogi, R. K. (1969) Seminal vesicles and sperm duct of an Indian catfish, Mystus tengara (Ham), with particular reference to their seasonal cycle. Acta Anat. 72, 624-639.

21. Schoonen, W. G. E. J., Lambert, J. G. D. (1986) Steroid metabolism in the seminal vesicles of the African catfish, Clarias gariepinus (Burchell), during the spawning season, under natural conditions, and kept in ponds. Gen. Comp. Endocrinol. 61, 355-367.

22. Schoonen, W. G. E. J., Lambert, J. G. D. (1987) Gas chromatographic-mass spectrometric analysis of steroids and steroid glucuronides in the seminal vesicle fluid of the African catfish, Clarias gariepinus. Gen. Comp. Endocrinol. 68, 375-386.

23. Schreck, C. B. (1973) Uptake of ${ }^{3} \mathrm{H}$-testosterone and influence of an antiandrogen in tissues of rainbow trout (Salmo giardneri). Gen. Comp. Endocrinol. 21, 60-68. 
24. Senthilkumaran, B., Joy, K. P. (1993) Annual cyclic, and castration and cyproterone acetate-induced, changes in sialic acid content of the seminal vesicle of the catfish, Heteropneustes fossilis (Bloch). Fish Physiol. Biochem. 10, 425-430.

25. Singh, M. S., Joy, K. P. (1997) Effects of administration of testosterone on seminal vesicle activity in the catfish Clarias batrachus during preparatory phase: A study correlating changes in testis and serum sex steroid levels. Acta Biol. Hung. 48, 421-430.

26. Singh, M. S., Joy, K. P. (1998) A comparative study on histochemical distribution of some enzymes related to steroid and glucuronide synthesis in seminal vesicle and testis of the catfish, Clarias batrachus. Zool. Sci. 15, 955-961.

27. Singh, M. S., Joy, K. P. (1998) Precocious recrudescence of seminal vesicle and testis in catfish, Clarias batrachus (Linn.), subjected to a long photoperiod regime. Ind. J. Exp. Biol. 36, 1264-1268.

28. Singh, M. S., Joy, K. P. (1998) Effect of administration of cyproterone acetate on seminal vesicle and testicular activity and serum testosterone and estradiol-17 $\beta$ levels in the catfish Clarias batrachus. Acta Biol. Hung. 49, 143-154.

29. Singh, M. S., Joy, K. P. (1999) Annual correlative changes in some biochemical contents of seminal vesicle and testis in the catfish Clarias batrachus (L.). Zool. Sci. 16, 345-356.

30. Singh, M. S., Joy, K. P. (2000) Methallibure inhibition of testicular and seminal vesicle activity in catfish, Clarias batrachus (Linn.): A study correlating changes in serum sex steroid profiles. Acta Biol. Hung. 51, 45-53.

31. Srivastava, A. K., Dey, S. B., Roy, S. K. (1983) Interaction of cyproterone acetate with sex hormone binding globulin of monkey plasma. Exp. Clin. Endocrinol. 82, 232-234.

32. Sundararaj, B. I., Nayyar, S. K. (1969a) Effect of extirpation of "seminal vesicles" on the reproductive performance of the male catfish, Heteropneustes fossilis (Bloch). Physiol. Zool. 42, 429-437.

33. Sundararaj, B. I., Nayyar, S. K. (1969b) Effects of castration and/or hypophysectomy on the seminal vesicles of the catfish, Heteropneustes fossilis (Bloch). J. Exp. Zool. 172, 369-384.

34. Sundararaj, B. I., Nayyar, S. K. (1969c) Effects of estrogen, SU-9055, and cyproterone acetate on the hypersecretory activity in the seminal vesicles of the castrate catfish, Heteropneustes fossilis (Bloch). J. Exp. Zool. 172, 399-408.

35. Tavolga, W. N. (1955) Effects of gonadectomy and hypophysectomy on prespawning behaviour in males of the gobiid fish, Bathygobius soporator. Physiol. Zool. 28, 218- 233.

36. Van den Hurk, R., Resink, J. W. (1992) Male reproductive system as sex pheromone producer in teleost fish. J. Exp. Zool. 261, 204-213.

37. Van den Hurk, R., Resink, J. W., Peute, J. (1987) The seminal vesicle of the African catfish, Clarias gariepinus. A histological, histochemical, enzyme-histochemical, ultrastructural and physiological study. Cell Tissue Res. 247, 573-582.

38. Van Weerd, J. H. (1990) Pheromones and Ovarian Growth in the African Catfish Clarias gariepinus. $\mathrm{Ph}$. D. Thesis, Agricultural University, Wageningen, The Netherlands.

39. Veneziale, C. M., Burns, J. M., Lewis, J. C., Büchi, K. A. (1977) Specific protein synthesis in isolated epithelium of Guinea-pig seminal vesicle: Effect of castration and androgen replacement. Biochem J. 166, 167-173.

40. Warren, L. (1959) The thiobarbituric acid assay of sialic acids. J. Biol. Chem. 234, 1971-1975. 
